\title{
Corrigendum: Detection of Apoptotic Cells Using Propidium lodide Staining
}

Andrea Newbold, Ben P. Martin, Carleen Cullinane, and Michael Bots

When this article was first published, the quantity of $\mathrm{NH}_{4} \mathrm{Cl}$ in the ACK Lysis Buffer recipe was incorrectly listed as $8.26 \mathrm{~g}$. The authors apologize for this error. The correct quantity of $\mathrm{NH}_{4} \mathrm{Cl}$ to be used in the ACK Lysis Buffer is $8.02 \mathrm{~g}$, which will produce a final concentration of $150 \mathrm{mM} \mathrm{NH}_{4} \mathrm{Cl}$. A corrected version of the recipe is below. In addition, the HTML version of the recipe (doi: 10.1101/ pdb.rec083295) and the PDF version of the article have been amended accordingly.

ACK Lysis Buffer

\begin{tabular}{lcc} 
Reagent & Quantity (for $1000 \mathrm{~mL}$ ) & Final concentration \\
\hline $\mathrm{NH}_{4} \mathrm{Cl}$ & $8.02 \mathrm{~g}$ & $150 \mathrm{mM}$ \\
$\mathrm{KHCO}_{3}$ & $1 \mathrm{~g}$ & $10 \mathrm{~mm}$ \\
$\mathrm{Na}_{2}$ EDTA & $37.2 \mathrm{mg}$ & $0.1 \mathrm{mM}$
\end{tabular}

Dissolve all reagents in $850 \mathrm{~mL}$ of $\mathrm{H}_{2} \mathrm{O}$. Adjust the $\mathrm{pH}$ to 7.2-7.4, and add $\mathrm{H}_{2} \mathrm{O}$ to 1000 $\mathrm{mL}$. Store for up to $6 \mathrm{mo}$ at room temperature. 


\section{Corrigendum: Detection of Apoptotic Cells Using Propidium lodide Staining}

Andrea Newbold, Ben P. Martin, Carleen Cullinane and Michael Bots

Cold Spring Harb Protoc; doi: 10.1101/pdb.corr104943

\begin{aligned} & \hline $\begin{array}{r}\text { Email Alerting } \\ \text { Service }\end{array}$ Receive free email alerts when new articles cite this article - click here. \\ & \hline $\begin{array}{r}\text { Subject } \\ \text { Categories }\end{array}$ Browse articles on similar topics from Cold Spring Harbor Protocols. \\ & \hline\end{aligned}

